\title{
NILAI EDUKATIF TOKOH BURLIAN DALAM NOVEL SI ANAK SPESIAL KARYA TERE LIYE: TINJAUAN SOSIOLOGI SASTRA SEBAGAI BAHAN AJAR CERITA INSPIRATIF
}

\author{
Febri Setiani ${ }^{1}$, Zainal Arifin ${ }^{2}$ \\ ${ }^{1}$ Universitas Muhammadiyah Surakarta \\ Jl. A. Yani, Pabelan, Kartasura, Surakarta \\ 1a310170130@student.ums.ac.id \\ ${ }^{2}$ Universitas Muhammadiyah Surakarta \\ Jl. A. Yani, Pabelan, Kartasura, Surakarta \\ 2za135@ums.ac.id
}

\begin{abstract}
ABSTRAK
Zaman semakin modern, ilmu pengetahuan mengalami perkembangan baik dari teknologi maupun pembelajarannya. Perkembangan tersebut membuat banyak dari kalangan pendidikan melupakan bidang kesusastraaan karena dinilai sulit dan membosankan. Sehingga menjadi seorang pendidik di zaman modern perlu inovasi dalam pembelajaran sastra. Salah satunya memanfaatkan nilai-nilai edukatif di dalam novel dan dijadikan bahan ajar dalam pembelajaran dapat memberikan inspirasi yang bermanfaat untuk siswa. Tujuan penelitian ini adalah untuk mendeskripsikan struktur, nilai edukatif melalui karater tokoh utama novel Si Anak Spesial karya Tere Liye serta kaitannya dengan bahan ajar cerita inspiratif Bahasa Indonesia. Metode penelitian ini adalah deskritif kualitatif dengan objek dalam penelitian ini yaitu objek material berupa kata, kalimat yang menunjukkan suatu watak serta perbuatan dalam hal ini merujuk kepada kepribadian dari tokoh Burlian dan objek formal yaitu nilai edukatif dari perilaku tokoh tersebut. Kemudian untuk subjek dalam penelitian ini adalah novel Si Anak Spesial karya Tere Liye.Teknik pengumpulan data yaitu teknik pustaka, teknik simak, dan teknik catat. Teknik analisis data dalam penelitian kualitatif ini menggunakan teknik analisis data interaktif. Hasil penelitian 1) terdapat struktur yang ditemukan antara lain, tema, alur, tokoh, penokohan, latar, gaya bahasa dan amanat. Keterkaitan antar unsur dalam novel tersebut bersama-sama membentuk suatu makna cerita yang banyak menyimpan nilainilai edukatif. 2) nilai edukatif yang ditemukan dalam penelitian ini antara lain: nilai edukatif religi, nilai edukatif moral, nilai edukatif sosial, dan nilai edukatif budaya. 3) nilai edukatif yang ditemukan relevan sebagai bahan ajar cerita inspiratif. Sesuai Kompetensi Dasar nilai edukatif telah mencakup kompetensi yang akan dicapai dalam pembelajaran cerita inspiratif.
\end{abstract}

Kata kunci: Nilai Edukatif, Sosiologi Sastra, Novel, Bahan Ajar

\section{ABSTRACT}

The more modern times, science has developed both from technology and learning. This development made many of the education community forget about literature because it was considered difficult and boring. So that being an educator in modern times needs innovation in literary learning. One of them is using educational values in novels and used as teaching materials in learning to provide useful inspiration for students. The purpose of this study is to describe the structure and educational value through the main character of Tere Liye's novel Si Anak Spesial by Tere Liye and its relation to the teaching materials 
for inspirational stories in Indonesian. This research method is descriptive qualitative with the object in this study, namely the material object in the form of words, sentences that show a character and actions in this case refers to the personality of the Burlian character and the formal object, namely the educational value of the character's behavior. Then for the subject in this study is the novel Si Anak Spesial by Tere Liye. Data collection techniques are library techniques, listening techniques, and note-taking techniques. The data analysis technique in this qualitative research uses interactive data analysis techniques. The results of the study 1) there are structures found, among others, themes, plot, characters, characterizations, settings, language styles and messages. The linkages between the elements in the novel together form a meaning of the story that holds a lot of educational values. 2) the educational values found in this study include: religious educational values, moral educational values, social educational values, and cultural educational values. 3) educational value found to be relevant as teaching material for inspirational stories. In accordance with the basic competencies, the educational value includes the competencies that will be achieved in learning inspirational stories.

Keywords: Educational Value, Sociology of Literature, Novels, Teaching Materials

\section{PENDAHULUAN}

Di zaman serba modern mungkin banyak dari kalangan khususnya pendidikan sedikit melupakan mengenai dunia kesusastraan. Sehingga banyak siswa yang banyak mengalami kesulitan jika sudah dihadapkan dengan teks sastra berupa cerita, puisi, pantun ataupun novel. Karena di zaman sekarang lebih memilih sesuatu yang mudah dan jelas. Namun, sebagai tenaga pendidik kita memerlukan sebuah inovasi dalam memberikan suatu pembelajaran di bidang sastra agar siswa tidak mengalami kesulitan bahkan mungkin sampai mengalami kebosanan saat membaca cerita, novel atau semua karya dalam bidang sastra. Dalam penelitian ini menjelaskan hasil analisis lain yaitu nilai edukatif dari " $\mathrm{Si}$ Anak Spesial". Selain itu dalam penelitian ini menjelaskan secara lebih spesifik antara nilai edukatif dari satu tokoh utama yaitu Burlian dengan bahan ajar pembelajaran yaitu cerita inspiratif. Hasil analisis nilai edukatif dari tokoh Burlian akan relevan dengan bahan ajar cerita inspiratif yaitu Kompetensi dasar (KD) 3.11 mata pelajaran Bahasa Indonesia kelas IX SMP. Relevansi pembelajarannya dengan nilai edukatif dalam suatu karya sastra dapat dijadikan bahan ajar dalam pembelajaran kelas dan dapat memberikan inspirasi yang bermanfaat untuk kehidupan siswa berdasarkan makna dalam suatu karya sastra tersebut.

Karya sastra adalah suatu cara seorang pengarang untuk melakukan refleksi mengenai kehidupan yang di dalamnya menyatukan antara daya imajinasi dan kreasi serta dukung oleh pengalaman atas kehidupan tersebut. Karya sastra bisa menarik untuk pembaca tidak lepas dari seorang pengarang yang menceritakan tempat kehidupan yang menggunakan daya imajinasinya (Djojosuroto, 2006:17). Karya sastra dalam penelitian ini adalah novel. Novel adalah suatu karya sastra yang di dalamnya memuat cerita baik fiksi maupun nyata yang sarat akan makna dan pembelajaran.

Kemudian novel juga bisa diartikan sebagai suatu cerita yang di dalamnya menceritakan interaksi manusia dengan sesama dan lingkungan, juga interaksinya dengan diri sendiri maupun dengan Tuhan yang memunculkan cerita mengenai berbagai masalah hidup manusia. Novel adalah hasil seorang pengarang melalui suatu dialog, kontemplasi, serta suatu reaksi yang dilakukan suatu proses secara intens terhadap kehidupan dan lingkungan, melalui penghayatan serta perenungan. Dengan kata lain novel adalah suatu karya sastra yang bersifat imajinatif yang dilandasi oleh kesadaran serta tanggung jawab kreatif sebagai karya seni yang memiliki unsur estetik yang menawarkan berbagai model 
kehidupan yang dianggap oleh seorang pengarang itu ideal (Al-Ma'ruf dan Nugraheni, 2017).

Pendekatan sosiologi dipilih penulis karena sifat tokoh tersebut berkaitan dengan unsur sosial lingkungan masyarakat dan dapat dijadikan suatu nilai edukatif atau nilai pendidikan yang dapat diterapkan dalam kehidupan sehari-hari. Nilai edukatif merupakan suatu hal penting yang bisa dijadikan suatu tuntunan untuk manusia baik jasmani dan rohani atau dalam pertumbuhan serta perkembangannya dalam tercapainya suatu kedewasaan. Serta sikap yang diwujudkan adalah sikap kehidupan dalam bersosial maupun individu yang didalamnya terdapat nilai pendidikan (Fatria, 2016). Seperti pendapat (Damono, 2003) sosiologi sastra merupakan suatu pendekatan di bidang sastra yang digunakan untuk memahami lebih dalam gejala sosial yang terdapat di luar sastra yang bertujuan untuk mengetahui struktur melalui pertimbangan segi-segi kemasyarakatan melalui analisis teks. Kemudian pendapata lain, sosiologi sastra merupakan cabang dari ilmu sosiologi. Secara umum sosiologi sastra adalah ilmu studi mengenai hubungan karya sastra dengan masyarakat. Karya sastra tersebut dilihat dari konteks sosial dapat mempengaruhi seorang pengarang dalam menciptakan suatu karya sastra untuk mengembangkan imajinasi karya sastranya terhadap peristiwa dalam kehidupan sosial bermasyarakat secara luas (Sunanda dan Arifin, 2020).

Media yang mudah digunakan untuk mengajarkan bagaimana cerita inspiratif dalam novel tersebut bisa dilakukan yaitu salah satunya melalui pembelajaran. Dari semua pembelajaran di sekolah pembelajaran yang tepat adalah pembelajaran Bahasa Indonesia. Dalam jenjang Sekolah Menengah Pertama terdapat kompetensi yang mengajarkan bagaiamana siswa perlu mengetahui bagaimana empati, kepedulian serta perasaan dari suatu cerita inspiratif. Maka dari itu untuk mencapai kompetensi pembelajaran tersebut diperlukan suatu cerita atau sumber pembelajaran yang benar-benar bisa membuat siswa tidak hanya sekedar tahu untuk kegiatan pembelajaran namun bisa dilakukan dalam kehidupan sehari-hari. Sehingga siswa selain bisa mencapai kompetensi pembelajaran juga bisa menerapkan perilaku-perilaku inspiratif dari tokoh di dalam novel.

\section{METODE}

Penelitian ini adalah deskriptif kualitatif. Penelitian deskritif kualitatif adalah suatu penelitian yang dilakukan oleh seorang peneliti agar memahami fenomena yang dialami subjek dalam suatu penelitian seperti perilaku, persepsi, motivasi, tindakan, dan lain lain. Wujud kata-kata dan bahasa dalam suatu konteks yang khusus alamiah secara dan deskripsi memanfaatkan berbagai metode ilmiah (Moleong, 2014: 6).

Objek dalam sebuah penelitian mencakup objek material dan objek formal. Objek material adalah bahan yang akan diteliti, dan dalam penelitian ini objek materialnya adalah adalah kata, kalimat yang menunjukkan suatu watak serta perbuatan dalam hal ini merujuk kepada kepribadian dari tokoh Burlian dalam novel Si Anak Spesial karya Tere Liye yang dapat dijadikan suatu nilai edukatif. Sedangkan objek formal adalah objek yang merujuk pada fokus penelitian, dan dalam penelitian ini objek formalnya adalah nilai edukatif atau nilai pendidikan dari perilaku tokoh tersebut. Kemudian untuk subjek dalam penelitian ini adalah novel Si Anak Spesial karya Tere Liye.

Penulis dalam memperoleh data dalam penelitian ini menggunakan tiga teknik pengumpulan data. Teknik yang dilakukan yaitu teknik pustaka, teknik simak, dan teknik catat. Data dalam penelitian ini diperoleh dengan membaca secara intensif, cermat serta mencatatnya. Kemudian disertai dengan kegiatan kepustakaan untuk menambah pengumpulan datanya. 
Teknik analisis data dalam penelitian kualitatif ini menggunakan teknik analisis data interaktif. Menurut Miles dan Huberman dalam (Sugiyono, 2014) suatu kegiatan analisis data kualitatif interaktif merupakan analisis yang dilakukan secara terus-menerus hingga selesai. Kemudian kegiatan analisis datanya meliputi reduksi data terlebih dahulu, kemudian dilanjutkan dengan menyajikan data dan terakhir menarik kesimpulan serta melakukan verifikasi. Analisis data ini dilaksanakan setelah kegiatan pengumpulan data.

\section{HASIL DAN PEMBAHASAN}

Berisi hasil penelitian. Hasil penelitian dapat dilengkapi dengan tabel, grafik, atau gambar. Bagian pembahasan memaparkan hasil pengolahan data, interpretasi hasil penelitian yang diperoleh, mengaitkan dengan sumber rujukan yang relevan sebagai justifikasi temuan.

Novel dalam penelitian ini adalah novel Si Anak Spesial karya Tere Liye. Novel tersebut banyak sekali nilai-nilai yang terkandung di dalamnya. Sesuai dengan penelitian ini, nilai edukatif dari novel Si Anak Spesial karya Tere Liye memiliki jumlah yang tidak sedikit. Sehingga peneliti banyak memiliki data nilai edukatif dan dapat dikaitkan dengan pembelajaran di sekolah yaitu bahan ajar cerita inspiratif. Dalam penelitian ini, nilai edukatif akan di dapat peneliti melalui pembacaan serta pencatatan dari perilaku tokoh utama novel yaitu Burlian. Sesuai dengan rumusan masalah dalam penelitian ini akan diuraikan terlebih dahulu struktur yang terdapat dalam novel. Kemudian nilai-nilai edukatif yang tedapat dalam novel dan kaitannya dengan bahan ajar cerita inspiratif.

\section{A. Struktur novel "Si Anak Spesial" karya Tere Liye}

Struktur dalam suatu karya sastra lebih dari sekedar unsur-unsur serta totalitasnya. Antar hubungan dalam suatu karya sastra menunjukkan suatu kualitas energetis unsur yang menghasilkan pemahaman bahwa karya sastra lebih dari sekedar pemahaman bahasa sebagai mediumya (Ratna, 2011).

1) Tema

Sesuai dengan penelitian Fadli (2017) tema adalah gagasan pokok yang mendasari pembahasan yang dibicarakan dalam sebuah novel. Gagasan pokok yang dasar inilah yang disebut tema. Novel Si Anak Spesial karya Tere Liye ini bertemakan kekeluargaan. Hal ini sesuai dengan isi keseluruhan cerita bagaimana keluarga Burlian yang menginspirasi karena Bapak, Mamak adalah contoh orang tua yang memiliki sikap keras namun selalu menumbuhkan pendidikan keluarga yang dapat menciptakan kepercayaan diri, keyakinan di dalam keluarga.

2) Alur

Berdasarkan penelitian Suprihatiningsih (2019) alur di dalam novel adalah suatu peristiwa-peristiwa yang terjadi di dalam sebuah novel. Pembagian alur dalam novel ada alar maju, mundur dan campuran. Alur dalam novel Si Anak Spesial karya Tere Liye ini adalah alur maju. Karena, di dalam novel ini menceritakan bagaimana masa kecil Burlian dengan segala cerita, peristiwa serta pengelaman yang banyak memiliki nilai-nilai edukatif yaitu dari Burlian lahir hingga ia dapat tumbuh dewasa dan dapat mewujudkan mimpinya untuk melajutkan sekolah di Tokyo.

3) Tokoh

Tokoh dalam novel "Si Anak Spesial" karya Tere Liye ini tentu Burlian sebagai tokoh utama dan ada banyak tokoh-tokoh yang terlibat untuk membangun cerita di dalam novel ini. Tentu saja dari keluarga Burlian terdapat tokoh Bapak, Mamak, Kak Pukat, Kak Eli dan Amelia. Kemudian guru Burlian Pak Bin. Tidak hanya itu terdapat tokoh teman Burlian yaitu Can, Ahmad, Munjib. Tokoh lain adalah Ibu Ahmad, Paman Unus, Bakwo 
Dar, Wak Lihan, Sersan Sergio dan Nakamura.

4) Penokohan

Penelitian Pusvita (2017) penokohan atau perwatakan adalah sifat yang ditunjukkan oleh tokoh dalam suatu karya sastra. Penokohan atau watak dalam novel Si Anak Spesial karya Tere Liye ini bermacam-macam. Setiap tokoh memiliki penokohan atua karakter yang berbeda-beda. Namun perbedaan tersebut membuat cerita maupun nilainilai edukatif dalam novel dapat tersampaikan. Burlian sebagai tokoh utama memiliki karakter sebagai anak yang pemberani, optimis, keras kepala, nakal namun memiliki mimpi serta keingintahuan yang besar. Hal ini sesuai dengan kutipan di dalam novel.

"Kau selalu saja ingin tahu urusan orang lain, Burlian." Bapak tertawa. Wajahku jadi terlipat sebal" (halaman 157).

Sebenarnya penokohan dalam novel Si Anak Spesial karya Tere Liye ini berbedabeda. Namun, hanya penokohan Burlian, Bapak dan Mamak saja yang ditunjukkan karena penulis menilai ketiga penokohan tersebut yang penting dalam novel ini.

5) Latar

Latar di dalam novel ini dibagi menjadi tiga, yaitu latar tempat, latar waktu dan latar suasana. Latar tempat dalam novel ini yaitu berlatar belakang di sebuah kampung yang terletak di kepulauan Sumatera. Hal ini sesuai dengan kutipan novel.

"Kampung kami terletak di kaki Bukit Barisan" (halaman 13)

Latar tempat dalam di dalam novel "Si Anak Spesial" karya Tere Liye ini sebenarnya banyak. Mulai dari rumah, sekolah, kebun, lapangan sepak bola hingga stasiun kereta.

Kemudian latar waktu dalam novel Si Anak Spesial karya Tere Liye ini diceritakan terjadi sekitar tahun 1980-an hal ini dibuktikan dalam novel bagaimana sekolah, lingkungan rumah, pekerjaan yang menunjukkan tahun 1980-an. Kemudian latar suasana dalam novel Si Anak Spesial karya Tere Liye ini ada beberapa yang muncul yaitu suasana menyeramkan, menegangkan serta mengharukan.

6) Gaya Bahasa

Novel Si Anak Spesial karya Tere Liye ini banyak akan gaya bahasanya. Selain itu bahasa yang digunakan dalam novel juga menggunakan bahasa Indonesia sehingga gaya bahasa maupun bahasa di dalam novel mudah dipahami. Walaupun terdapat selipan bahasa daerah dan bahasa asing (Jepang dan Belanda) dijelaskan pula terjemahannya sehingga cerita di dalam novel mudah dipahami pembaca.

7) Amanat

Amanat atau pesan dalam novel menuturkan bahwa pendidakan keluarga adalah hal penting yang dapat menjadikan pribadi seseorang terbentuk. Pribadi yang baik bermula dari sebuah keluarga. Sejak kecil Burlian selalu diberi pendidikan oleh keluarga menjadi anak yang spesial agar selalu menumbuhkan kepercayaan diri, optimis, keyakinan, dan menjadi pegangan hidup Burlian dari masa kecil hingga sukses mewujudkan cita-citanya saat dewasa. Selain itu amanat dalam novel berbakti kepada orang tua adalah suatu kewajiban anak. Burlian selalu membantu pekerjaan Bapak dan Mamaknya, kemudian selalu membantu teman dan ramah dengan siapapun. Semua perilaku Burlian tersebut berawal dari pendidikan keluarga. Sehingga begitu pentingnya pendidikan keluarga yang harus ditanamkan untuk membentuk karakter dan sifat anak.

\section{B. Nilai Edukatif novel "Si Anak Spesial" karya Tere Liye}

Menurut Mulyana (2004) nilai edukatif atau nilai pendidikan merupakan segala sesuatu yang dapat diambil dari sikap atau perilaku dalam sebuah media. Nilai edukatif memiliki hakikat dari sebuah konteks pendidikan di Indonesia yaitu pendidikan nilai, 
sebuah nilai-nilai luhur pendidikan yang bersumber dari budaya bangsa Indonesia yang bertujuan untuk membina kepribadian generasi muda bangsa. Beberapa nilai edukatif dalam novel "Si Anak Spesial" karya Tere Liye yang ditemukan antara lain nilai edukatif religi, nilai edukatif moral, nilai edukatif budaya. Berikut ini tabel nilai-nilai eduktif yang ditemukan dalam novel "Si Anak Spesial" karya Tere Liye.

Tabel 1. Nilai Edukatif Novel Si Anak Spesial

\begin{tabular}{|c|c|c|c|}
\hline \multicolumn{4}{|c|}{ Nilai Edukatif } \\
\hline Religi & Moral & Sosial & Budaya \\
\hline $\begin{array}{l}\text { 1. Rajin Mengaji } \\
\text { 2. Selalu Berdoa }\end{array}$ & $\begin{array}{l}\text { 1. Menjaga Harga } \\
\text { Diri } \\
\text { 2. Rajin } \\
\text { Membantu } \\
\text { Orang Tua } \\
\text { 3. Pekerja Keras } \\
\text { 4. Rasa Ingin } \\
\text { Tahu } \\
\text { 5. Peduli } \\
\text { 6. Bersyukur } \\
\text { 7. Mau Belajar } \\
\text { dengan Orang } \\
\text { Lain tanpa } \\
\text { Pamrih dan } \\
\text { Malu } \\
\text { 8. Optimis } \\
\text { Meraih Mimpi } \\
\text { 9ekun } \\
\text { 10. Dapat } \\
\text { Dipercaya } \\
\text { 11. Semangat } \\
\text { Belajar } \\
\text { 12. Pemberani } \\
\text { dan Cerdas } \\
\text { 13. Sopan Santun } \\
\text { 14. Kasih Sayang } \\
\text { 15. Patuh kepada } \\
\text { Orang Tua }\end{array}$ & $\begin{array}{l}\text { 1. Bersosial } \\
\text { Tinggi } \\
\text { 2. Sopan Santun } \\
\text { di Masyarakat } \\
\text { 3. Selalu } \\
\text { Mengucapkan } \\
\text { "Terima kasih" } \\
\text { 4. Mudah Bergaul } \\
\text { 5. Mudah Berbaur } \\
\text { di Masyarakat } \\
\text { 6. Jujur } \\
\text { 7. Menginspirasi }\end{array}$ & $\begin{array}{l}\text { 1. Budaya atau } \\
\text { Kebiasaan } \\
\text { Burlian di Pagi } \\
\text { Hari } \\
\text { 2. Budaya } \\
\text { Mempercayai } \\
\text { Leluhur } \\
\text { Kampung }\end{array}$ \\
\hline
\end{tabular}

\section{1) Nilai Edukatif Religi}

Mirna (2019) nilai edukatif religi adalah suatu nilai yang menjadi human nature yang bergejala dalam lubuh hati secara sadar. Nilai edukatif religi berfungsi agar manusia menjadi seseorang yang lebih baik sesuai tuntutan agama dan Tuhannya. Kemudian jika dikaitkan antara suatu karya sastra dan nilai religi bisa menjadi suatu renungan yang bersifat batin untuk penikmat suatu karya sastra yang bersumber dari nilai-nilai religi tersebut.

“Kami pulang mengaji dari rumah Nek Kiba”. (halaman 102).

"Iya, ini juga sudah bergegas". Aku mengepit Al-Quran erat-erat, melangkah lebih cepat. (halaman 102). 
Dalam kutipan tersebut menunjukkan bahwa Burlian dan kakaknya yang ditunjukkan dengan kata "kami" rajin mengaji dan selalu pulang bersama dari rumah Nek Kiba. Kemudian dari kutipan kedua masih di halaman 102 tokoh Burlian dijelaskan selesai mengaji dan bergegas pulang dengan mengapit Al-Quran.

\section{2) Nilai Edukatif Moral}

Rahmawati (2019) nilai edukatif moral merupakan peraturan tingkah laku setiap invidu maupun kelompok sesuai dengan adat istiadat masyarakatnya. Moral dapat diartikan sebuah norma yang di dalamnya mengatur konsep kehidupan yang sangat dijunjung tinggi oleh masyarakat.

"...dari sekolah, diajak Mamak membantu apa saja tidak masalah. Mamak mengangguk, menyuruh bergegas sarapan”. (halaman 22).

"Ini yang keempat kali aku dan Kak Pukat tersengal naik-turun bukit, dengan baju mulai kotor oleh debu, wajah cemong, keranjang rotan yang disesaki potongan kayu bakar". (halaman 25).

Kedua kutipan tersebut salah satu contoh sikap Burlian yang menunjukkan nilai edukatif moral. Burlian memiliki karakter suka membantu orang tua. Hal ini dibuktikan saat pagi hari Burlian sudah membantu Mamak. Selain itu, Burlian dalam kutipan pertama "membantu apa saja tidak masalah" menunjukkan bahwa Burlian dengan senang hati membantu apa saja pekerjaan mamak. Kemudian kutipan kedua menunjukkan Burlian rajin saat membantu Mamak mengangkat kayu bakar. Walaupun beberapa kali merasa capek saat naik turun bukit, Burlian tetap rajin membantu Mamak.

\section{3) Nilai Edukatif Sosial}

Nilai edukatif sosial juga menjadi sebuah penentu seseorang dalam bersikap dan saat menyelesaikan masalah. Ini dapat membuat seseorang mengerti akan pentingnya kehidupan bermasyarakat satu individu dengan individu lain. Hal ini sejalan dengan penelitian Nurachmana (2020) nilai edukatif sosial adalah nilai edukatif yang berkaitan dengan kemasyarakatan dan bagaimana seseorang berperilaku di masyakarat.

“...Bila perlu, besok kugambarkan di papan tulis saat istirahat sekolah. Sekarang mari kita hajar lawan. Dengar, penonton sudah memanggilmanggil nama kau...". (halaman 58-59).

"Aku tahu dan belajar banyak hal dari Nakamura. Dalam satu percakapan ringan saat istirahat petang, Nakamura bercerita bahwa pekerjaan mereka...". (halaman 178).

Kedua kutipan tersebut salah satu contoh sikap Burlian yang menunjukkan nilai edukatif sosial. Kutipan pertama menunjukkan Burlian memiliki karakter yang bersosial tinggi dengan menyemangati temannya. Burlian selalu menyemangati temannya, Ahmad untuk bersemangat saat mengikuti pertandingan sepak bola. Selain itu di dalam novel ini juga menunjukkan bahwa Burlian tidak pernah membeda-bedakan teman. Burlian selalu berteman dengan siapa saja. Kemudian kutipan kedua menunjukkan Burlian memiliki karakter yang mudah bergaul di masyakarat. Sesuai konteks di halaman 178, Burlian mudah bergaul dengan orang yang baru di kenal dengan saling bercerita dan selalu ramah. Hal ini menjadi hal penting di masyakarat dengan selalu ramah dengan orang lain, walaupun baru dikenal.

\section{4) Nilai Edukatif Budaya}

Nilai budaya juga penting untuk mengetahui karakteristik setiap kehidupan suatu masyarakat. Dan hal ini menjadi suatu ciri khas yang dimiliki kelompok masyarakat dan berbeda antar kelompok masyakarat lain. Sesuai dengan penelitian Mirna (2019) nilai 
edukatif budaya adalah suatu nilai yang bersumber dari suatu pengamatan gelaja nyata seperti tingkah laku dan merupakan suatu hasil dari konsep yang tumbuh di masyarakat.

"Orang-orang tua kampung kami punya perhitungan sendiri dengan kebiasaan alam. Dengan pengalaman berpuluh-puluh tahun, biasanya jarang meleset. Jadi hujan tidak akan turun siang ini. Aku melangkah lebih ringan". (halaman 69).

"Burlian, Pukat, leluhur kita hidup bersisian dengan alam lebih dari ratusan tahun. Mereka hidup dari kasih sayang hutan yang memberikan segalanya. Maka sudah sepatutnya mereka membalas kebaikan itu dengan menjaga hutan dan seluruh isinya”. (halaman 254).

Kedua kutipan tersebut salah satu contoh sikap Burlian yang menunjukkan nilai edukatif budaya. Kedua kutipan tersebut menunjukkan bahwa Burlian yang besar dan hidup di kampung selalu mempercayai leluhur kampungnya. Karena, hal ini salah satu budaya dan kepercayaan masyarakat kampung. Menjadi nilai edukatif budaya karena menghargai bagaimana suatu budaya dalam kampung yang tetap dihormati dengan mempercayai leluhur-leluhur kampung.

\section{Relevansi Nilai Edukatif novel "Si Anak Spesial" karya Tere Liye dengan bahan ajar Cerita Inspiratif}

Relevansi nilai edukatif novel "Si Anak Spesial" karya Tere Liye dengan bahan cerita inspiratif ini ditunjukkan dengan mengkaitkan antara KD 3.11 mata pelajaran Bahasa Indonesia kelas IX SMP dengan nilai-nilai edukatif yang telah ditemukan. Sebelum menunjukkan relevansinya, berikut adalah KD 3.11 mata pelajaran Bahasa Indonesia kelas IX SMP.

3.11 Mengidentifikasi isi ungkapan simpati, kepedulian, empati, atau perasaan pribadi dari teks cerita inspiratif yang dibaca dan didengar.

Setelah penjelasan nilai-nilai edukatif novel "Si Anak Spesial" karya Tere Liye di atas, dapat dilihat bahwa nilai-nilai edukatif tersebut dapat dijadikan bahan ajar cerita inspiratif karena sesuai KD 3.11 tersebut pembelajaran cerita inspiratif berisi suatu ungkapan, simpati, kepedulian, empati atau perasaan pribadi darti suatu teks. Maka dari itu nilai-nilai edukatif tersebut dapat dijadikan bahan ajar karena di dalam pembelajaran cerita inspiratif membahas bagaimana siswa mampu menunjukkan dalam suatu cerita tersebut dapat menginspirasinya. Dengan pembacaan serta pemahaman cerita siswa dapat menunjukkan inspirasi apa yang terdapat dalam cerita.

Penelitian ini menunjukkan bahwa nilai-nilai edukatif novel "Si Anak Spesial" karya Tere Liye dapat dijadikan bahan ajar cerita inspiratif. Jika dikaitkan dengan pengertian bahan ajar sendiri menurut Depdiknas (2008) adalah segala bentuk bahan yang digunakan untuk membantu guru dalam melaksanakan kegiatan belajar mengajar. Sehingga nilai edukatif tersebut sebagai bahan guru dalam pembelajaran cerita inspiratif, karena sesuai Kompetensi Dasar (KD) pencapaikan pembelajaran cerita inspiratif. Nilainilai edukatif telah mencakup kompetensi yang akan dicapai dalam pembelajaran cerita inspiratif. Kompetensi Dasar yang akan dicapai mengenai ungkapan simpati, kepedulian, empati atau perasaan pribadi dati suatu teks relevan dengan nilai-nilai edukatif yang ditemukan dalam novel.

Hasil analisis nilai-nilai edukatif novel "Si Anak Spesial" karya Tere Liye dapat dijadikan inovasi pembelajaran cerita inspiratif dengan menggunakan karya sastra novel sebagai sumber bahan ajarnya. Kemudian ditemukan nilai-nilai edukatif yaitu nilai 
edukatif religi, nilai edukatif moral, nilai eduktif sosial dan nilai edukatif budaya. Hasil analisis tersebut sesuai dengan hasil penelitian Mirna (2019) dalam novel Kaki Saya Bulat karya Suharyo Widagdo ditemukan empat nilai pendidikan yaitu nilai pendidikan religius, nilai pendidikan moral, nilai pendidikan sosial, dan nilai pendidikan budaya. Hal ini menunjukkan bahwa secara garis besar hasil penelitian nilai edukatif dari suatu novel di dominasi keempat nilai tersebut.

Nilai edukatif paling banyak ditemukan adalah nilai edukatif moral. Karena dalam penelitian ini nilai edukatif yang ditemukan berdasarkan karakter tokoh utama yaitu, Burlian. Hal ini sejalan dengan hasil penelitian Nurhuda (2017) yang menunjukkan bahwa terdapat hubungan sosial antar tokoh di dalam novel yang dapat dijadikan bahan ajar. Nilai edukatif moral banyak ditemukan di dalam novel karena Burlian sebagai tokoh utama selalu dibiasakan dan di didik oleh Bapak dan Mamak yang menumbuhkan pendidikan keluarga yang dapat menciptakan kepercayaan diri, keyakinan di dalam diri anak-anaknya, mengajarkan bagaimana berperilaku yang baik, termasuk Burlian. Sehingga dalam diri Burlian tertanam karakter yang bermoral karena didikan Bapak dan Mamaknya.

Nilai edukatif tersebut sebagai bahan ajar guru dalam pembelajaran cerita inspiratif, karena sesuai Kompetensi Dasar (KD) pencapaikan pembelajaran cerita inspiratif. Ini sesuai dengan hasil penelitian Madyananda (2017) nilai pendidikan dalam novel Padang Bulan dapat dimanfaatkan dalam pembelajaran Bahasa Indonesia di jenjang SMP. Sehingga, hasil analisis nilai pendidikan dalam suatu novel terdapat relevansi terhadap pembelajaran Bahasa Indonesia SMP. Nilai-nilai edukatif telah mencakup kompetensi yang akan dicapai dalam pembelajaran cerita inspiratif. Kompetensi Dasar yang akan dicapai mengenai ungkapan simpati, kepedulian, empati atau perasaan pribadi dati suatu teks relevan dengan nilai-nilai edukatif yang ditemukan dalam novel.

\section{SIMPULAN}

Simpulan dari penelitian ini adalah berdasarkan analisis data pertama, ditemukan keterkaitan struktur yang saling membangun di dalam novel. Struktur yang ditemukan antara lain, tema, alur, tokoh, penokohan, latar, dan gaya bahasa. Keterkaitan antar unsur dalam novel tersebut bersama-sama membentuk suatu makna cerita yang banyak menyimpan nilai-nilai edukatif. Sehingga hasil analisis yang kedua, ditemukan nilai edukatif sesuai dengan perilaku tokoh utama yaitu Burlian novel "Si Anak Spesial" karya Tere Liye. Nilai edukatif yang ditemukan adalah nilai edukatif religi, nilai edukatif moral, nilai edukatif sosial, dan nilai edukatif budaya. Semua nilai edukatif tersebut berjumlah 26 data nilai. Nilai edukatif paling banyak ditemukan adalah nilai edukatif moral.

Ketiga, hasil analisis struktur dan nilai edukatif dalam novel "Si Anak Spesial" karya Tere Liye ini relevan sebagai bahan ajar cerita inspiratif. Sesuai Kompetensi Dasar (KD) nilai-nilai edukatif telah mencakup kompetensi yang akan dicapai dalam pembelajaran cerita inspiratif. Karena Nilai-nilai edukatif yang tentunya bersumber dari perilaku tokoh yaitu nilai edukatif religi, moral, sosial dan budaya yang menunjukkan suatu simpati, kepedulian, empati atau perasaan pribadi. 


\section{DAFTAR PUSTAKA}

Al-Ma'ruf, Ali Imron dan Farida Nugrahani. 2017. Pengkajian Sastra Teori dan Aplikasi. Surakarta: CV. Djiwa Amarta Press.

Depdiknas. 2008. Panduan Pengembangan Bahan Ajar. Jakarta: Direktorat Pembinaan Sekolah Menengah Atas Dirjen Manajemen Pendidikan Dasar dan Menengah Depdiknas.

Djojosuroto, Kinayati. 2006. Analisis Teks Sastra dan Pengajarannya. Yogyakarta: Pustaka.

Damono, Sapardi Djoko. 2003. Kesusasteraan Indonesia Modern, Beberapa Catatan. Jakarta: Gramedia.

Fadli, Muhammad., et al. 2017. "Analisis Struktural dan Nilai Pendidikan Novel Gedhong Setan Karya Suparto Brata serta Relevansinya sebagai Materi Pembelajaran Novel Berbahasa Jawa. PAEDAGOGIA: Jurnal Penelitian Pendidikan. 20(2): 166-184. https://doi.org/10.20961/paedagogia.v20i2.12452

Khair, U., \& Misnawati, M. (2022). Indonesian language teaching in elementary school: Cooperative learning model explicit type instructions chronological technique of events on narrative writing skills from interview texts. Linguistics and Culture Review, 6, 172-184.

Fatria, Fita. 2016. "Analisis Nilai-Nilai Edukatif Dalam Novel Sepatu Dahlan Karya Khrisna Pabichara”. Jurnal Penelitian Pendidikan Bahasa dan Sastra. 1(1): 1-10. https://jurnal-lp2m.umnaw.ac.id/index.php/JP2BS/article/view/17

Madyananda, Ulinnuha dan Umi Yaryati. 2017. "Nilai Pendidikan Novel Padang Bulan serta Pemanfaatannya dalam Pembelajaran Bahasa Indonesia di SMP”. Jurnal Pendidikan Bahasa dan Sastra Indonesia. 2(2): 63-68. http://dx.doi.org/10.26737/jp$\underline{\text { bsi.v2i2.248 }}$

Misnawati, M., Linarto, L., Poerwadi, P., Nurachmana, A., Purwaka, A., Cuesdeyeni, P., ... \& Asi, Y. E. (2021). Sexuality Comparison in Novel Eleven Minutes With Tuhan Izinkanlah Aku Menjadi Pelacur! Memoar Luka Seorang Muslimah. AKSIS: Jurnal Pendidikan Bahasa dan Sastra Indonesia, 5(1), 1-14.

Misnawati, M., Poerwadi, P., \& Rosia, F. M. (2020). Struktur Dasar Sastra Lisan Deder. Pedagogik: Jurnal Pendidikan, 15(2), 44-55.

Mirna, Wa., 2019. "Analisis Nilai-Nilai Pendidikan dalam Novel "Kaki Saya Bulat" Karya Suharyo Widagdo. Jurnal Lingue: Bahasa, Budaya, dan Sastra. 1(2): 113-127. http://dx.doi.org/10.33477/lingue.v1i2.1187

Moleong, L. J. (2014). Metodologi Penelitian Kualitatif. Bandung: PT Remaja Rosdakarya 
Mulyana, Rahmat. 2004. Mengartikulasikan Pendidikan Nilai.Bandung: Alfabeta.

Nurachmana, Alifiah. Et al. 2020. Analisis Nilai Edukatif dalam Novel Orang-Orang Biasa Karya Andrea Hirata: Tinjauan Sosiologi Sastra. ENGGANG: Jurnal Pendidikan, Bahasa, Sastra, Dan Budaya. 1(1): 57-66. journal.upr.ac.id/index.php/enggang/article/view/2464

Nurhuda, Teguh Alif., t al. 2017. "Kajian Sosiologi Sastra dan Pendidikan Karakter dalam Novel Simple Miracles Karya Ayu Utami Serta Relevansinya pada Pembelajaran Sastra di SMA". Jurnal Ilmiah DIDAKTIKA. 18(1): 103-117. http://dx.doi.org/10.22373/jid.v18i1.3090

Perdana, I., \& Misnawati, M. P. (2019). Cinta dan Bangga Berbahasa Indonesia Di Perguruan Tinggi. SPASI MEDIA.

Pusvita, Winda Dewi. 2017. "Nilai-Nilai Pendidikan Karakter Pada Novel Ayah Karya Andrea Hirata". LEKSEMA: Jurnal Bahasa dan Sastra. 2(1): 51-63. http://dx.doi.org/10.22515/ljbs.v2i1.652

Rahmawati, Erni., et al. 2019. "Nilai-Nilai Pendidikan yang Terkandung dalam Ritual Kangkilo pada Masyarakat Muna Desa Warambe". Jurnal BASTRA: Bahasa dan Sastra. 4(1): 169-183. http://dx.doi.org/10.36709/jb.v4i1.10730

Ratna, Nyoman Kutha. 2011. Antropologi Sastra: Peranan Unsur-unsur Kebudayaan dalam Proses Kreatif. Yogyakarta: PT Pustaka Pelajar.

Sudjiman, Panuti. 1988. Memahami Cerita Rekaan. Jakarta Pusat: Pustaka Jaya.

Sugiyono, Sugiyono. 2014. Metode Penelitian Pendidikan. Bandung: Alfabeta.

Sunanda, Adyana dan Zainal Arifin. 2020. Pengantar Teori Sastra. Surakarta: Muhammadiyah University Press.

Suprihatiningsih, Retno., et al. 2019. "Novel Wasripin dan Satinah Karya Kuntowijoyo: Analisis Struktur dan Nilai Pendidikan Karakter". BASASTRA: Jurnal Bahasa, $\begin{array}{llll}\text { Sastra, } & \text { dan } & \text { Pengajarannya. }\end{array}$ https://doi.org.10.20961/basastra.v7i2.37787 